\title{
Utilization of Social Media as A Means of Socialization to Prevent The Spread Of Covid-19 In The Youth Community in Kudus District
}

\author{
Munawar Kholil \\ Universitas Sebelas Maret \\ munawarkholil@staff.uns.ac.id
}

\section{Article History}

accepted 31/08/2020

\begin{abstract}
The lack of understanding of the public in Kudus Regency regarding preventing the spread of Covid-19 makes people continue their activities as usual without following the health protocols that have been published in the Kudus Regent Circular. Many young people do activities outside the home, such as in coffee shops or hanging out in public spaces, ignoring physical distancing and not wearing masks. The existence of these conditions requires an increase in understanding for youth about the importance of preventing the spread of Covid-19 by utilizing social media. The methods used in this activity are collecting material, making videos / images for social media, editing videos and images, and uploading these videos on various social media such as YouTube and Instagram TV, while images are uploaded on Instagram and Twitter. The output of this activity is an increase in the understanding of young people about preventing the spread of Covid-19, so as to minimize the spread of Covid-19 in Kudus Regency.

Keywords: Community Understanding, Social Media, Covid-19.
\end{abstract}

\begin{abstract}
Abstrak
Kurangnya pemahaman masyarakat di Kabupaten Kudus mengenai pencegahan penyebaran Covid-19 menjadikan masyarakat tetap beraktivitas seperti biasa tanpa mengikuti protokol kesehatan yang sudah diterbitkan dalam Surat Edaran Bupati Kudus. Banyak anak muda yang melakukan kegiatan di luar rumah, seperti di warung kopi atau nongkrong di ruang-ruang publik dengan mengabaikan physical distancing dan tidak menggunakan masker. Adanya kondisi tersebut diperlukan peningkatan pemahaman bagi para pemuda akan pentingnya pencegahan penyebaran Covid-19 dengan memanfaatkan media sosial. Metode yang dilakukan dalam kegiatan ini adalah mengumpulkan materi, pembuatan video/gambar untuk media sosial, editing video dan gambar, dan mengupload video tersebut diberbagai media sosial seperti youtube dan instagram TV, sedangkan untuk gambar diupload di instagram dan twitter. Luaran dari kegiatan ini adalah meningkatnya pemahaman para permuda mengenai pencegahan penyebaran Covid19, sehingga dapat meminimalisir penyebaran Covid-19 di Kabupaten Kudus.
\end{abstract}

Kata kunci: Pemahaman Masyarakat, Media Sosial,Covid-19.

Social, Humanities, and Education Studies (SHEs): Conference Series https://jurnal.uns.ac.id/shes 


\section{PENDAHULUAN}

Kabupaten Kudus merupakan salah satu kabupaten yang terletak di Provinsi Jawa Tengah. Kabupaten Kudus juga terkena dampak dari penyebaran virus Covid-19 (Coronavirus Disease 2019) yang sedang melanda berbagai wilayah saat ini. Tercatat sejak tanggal 15 Mei 2020, terdapat sebanyak 13 warga Kudus yang positif terjangkit virus Covid-19, kemudian terdapat sebanyak148 warga yang berstatus OTG (Orang Tanpa Gejala), lalu terdapat sebanyak 95 warga yang berstatus ODP (Orang Dalam Pantauan) dan terdapat sebanyak 83 warga yang berstatus PDP (Pasien Dalam Pengawasan) (BPBD, 2020) dan dapat mengalami peningkatan kembali. Dengan banyaknya jumlah kasus orang terdampak Covid-19 yang ada di Kabupaten Kudus, tidak membuat masyarakat Kabupaten Kudus sadar akan mengenai betapa bahayanya penyebaran virus Covid-19 ini. Hal ini dapat dilihat dari aktivitas yang terjadi di Kabupaten Kudus masih sama seperti biasa seakaan tidak terdampak virus Covid-19, bahkan banyak sekali anak muda atau juga disebut pemuda yang masih saja berkeliaran tanpa mengkhawatirkan kesehatannya. Apabila mengacu dalam Surat Edaran Bupati Kudus, Nomor: 440/0920/38.00/2020 tentang Peningkatan Kewaspadaan Terhadap Risiko Penularan Infeksi Corona Virus Disease (Covid-19) di Kabupaten Kudus, dinyatakan adanya kewajiban setiap warga untuk melaksanakan protokol kesehatan untuk mencegah penyebaran virus Covid-19.

Dalam penyisiran mendadak (sidak) yang sudah dilakukan oleh Bupati Kudus, Bapak HM Hartopo, masih banyak sekali ditemukan kerumunan anak muda yang sedang nongkrong di ruang publik seperti balai jagong, sekitar GOR dan Coffeshop dan bahkan tidak mengenakan masker serta tidak menerapkan konsep physical distancing yang dicanangkan serta dianjurkan oleh pemerintah (Mohammad, Y. 2020). Pemuda yang seharusnya menjadi kelompok masyarakat sipil yang memiliki jangkauan informasi yang luas dan sumber daya potensial untuk mendorong kebijakan yang efektif dalam memastikan pencegahan dan pengendalian virus Covid-19 (Pranita, E. 2020), kondisinya sering meremehkan penyebaran kasus virus Covid-19 dengan beranggapan bahwa dirinya memiliki imunitas yang baik dibanding dengan masyarakat selain dirinya sehingga tidak akan terkena virus Covid-19. Akan tetapi mereka lupa bahwasannya mereka bisa menjadi pembawa (carrier) virus Covid-19 tersebut ke anggota keluarga dirumah maupun lingkungan sekitarnya dengan keadaan orang tanpa gejala (OTG). Beberapa kasus orang tanpa gejala (OTG) yang sudah terjadi, si penderita tidak merasakan sama sekali gejala virus Covid-19 ini, akan tetapi setelah dilakukan pemeriksaan ditemukan jejak virus yang dibawa. Kasus seperti inilah yang dapat memicu terjadinya peningkatan kasus terjangkit virus Covid-19 pada suatu wilayah.

Berdasarkan kondisi yang sudah terpapar diatas serta terjadi di lapangan maka sangat diperlukan penyelenggaraan kegiatan promosi dalam rangka pencegahan serta pembatasan penyebaran virus Covid-19 dengan meningkatkan pemahaman kepada masyarakat khususnya masyarakat Kabupaten Kudus, terutama pada anak muda atau pemuda agar lebih memahami betapa pentingnya membatasi penyebaran virus Covid19. Salah satu sarana yang dirasa paling efektif dan tepat sasaran untuk promosi kegiatan tersebut adalah dengan melalui media sosial. Tingginya angka masyarakat pengguna media sosial terutama di kalangan anak muda (milenial) saat ini menjadikan salah satu faktor utama dalam penentuan sarana promosi kegiatan pencegahan penyebaran virus Covid-19. Penggunaan media sosial ini diharapkan dapat efektif untuk sosialisasi pencegahan penyebaran virus Covid-19 seperti kepatuhan akan pentingnya physical distancing yang dipromosikan oleh pemerintah setempat. Sehingga diharapkan angka terjangkit kasus virus Covid-19 yang ditemukan di Kabupaten Kudus dapat ditekan hingga seminimal mungkin. 


\section{METODE}

Lokasi dilakukannya kegiatan ini di Desa Bakalankrapyak, RT 03 / RW 03, Kelurahan Bakalan Karpyak, Kecamatan Kaliwungu, Kabupaten Kudus. Metode yang dilakukan dalam kegiatan ini adalah dengan mengumpulkan materi dari berbagai sumber untuk mengetahui secara mendalam mengenai pencegahan penyebaran Covid-19, kemudian materi-materi tersebut diringkas dan dibuat menjadi video/gambar untuk media sosial, selanjutnya materi media sosial dibuat yang menarik dengan berbagai tema agar dapat mudah dipahami dan menarik banyak perhatian, kemudian dilakukannya proses editing video dan gambar agar bisa dipublish diberbagai media sosial. Proses editing video menggunakan aplikasi Adobe Premiere dan editing gambar menggunakan aplikasi Adobe Spark Post. Setelah video dan gambar sudah jadi, maka video tersebut diupload diberbagai Media Sosial seperti Youtube dan Instagram TV, kemudian untuk gambar diupload di media sosial seperti Instagram dan Twitter. Pemilihan Media Sosial tersebut didasarkan pada pengguna dari Media Sosial tersebut kebanyakan merupakan anak muda, sehingga diharapkan adanya pemahaman tentang penyebaran Covid-19 bagi anak muda.

\section{HASIL DAN PEMBAHASAN}

Berdasarkan hasil yang sudah dilakukan, terdapat beberapa materi yang diupload ke Instagram dan Twitter, serta terdapat juga materi yang diupload ke Youtube dan Instagram TV (IGTV). materi tersebut sebagai berikut :

\section{Penjelasan mengenai istilah OTG, ODP \& PDP.}

Banyaknya istilah - istilah yang muncul seiringan dengan mewabahnya virus Covid-19 membuat sebagian besar masyarakat bingung dalam memahami. Perlu adanya penjelasan mendalam terkait istilah tersebut. Pembuatan poster dengan desain yang menarik dan konten yang berisi terkait dengan istilat orang tanpa gejala (OTG), orang dalam pantauan (ODP) dan pasien dalam pengawasan (PDP) yang kemudian dipublikasikan melalui Instagram dan Twitter. Diharapkan setelah membuka dan membaca postingan yang berisi poster istilah, masyarakat Kabupaten Kudus khususnya anak muda dapat mengetahui dengan benar mengenai konsep dasar dan perbedaan istilah yang digunakan untuk memberikan status bagi orang yang terkena Covid-19.
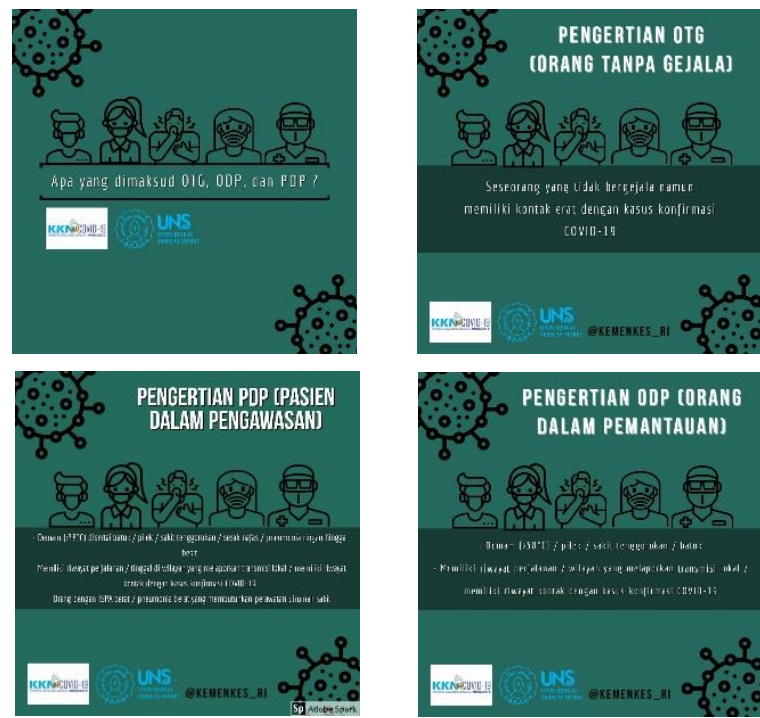

Gambar 1. Penjelasan Istilah Terkait OTG, ODP \& PDP 


\section{Putus Rantai Penularan Covid-19 serta Ajakan Cuci Tangan.}

Salah satu langkah pembatasan penyebaran virus Covid-19 yang dianjurkan Badan Kesehatan Dunia (WHO) dan Pemerintah Indonesia adalah mencuci tangan secara rutin. Penyebaran virus Covid-19 yang tidak terlihat mengharuskan penerapan protokol kesehatan yang intensif. Pemberlakuan protokol kesehatan khususnya cuci tangan diharapkan dapat memutus mata rantai penyebaran virus Covid-19. Hal ini dilakukan untuk menjaga kebersihan telapak tangan setelah melakukan aktivitas.

Gambar 3 menjelaskan terkait beberapa cara yang dapat mencegah penyebaran virus Covid-19 dan merupakan protokol kesehatan yang diusung oleh Pemerintah Indonesia melalui Kementerian Kesehatan.Terdapat beberapa hal yang termasuk dalam protokol kesehatan dan wajib dilakukan apabila sedang diluar rumah atau berpergian. Salah satunya yaitu penggunaan masker yang baik dan benar. Salah satu penekanan tujuan publikasi poster ini adalah menghimbau kepada masyarakat Kabupaten Kudus terkhusus anak muda untuk senantiasa mengingat dan menerapkan protokol kesehatan dimanapun berada.
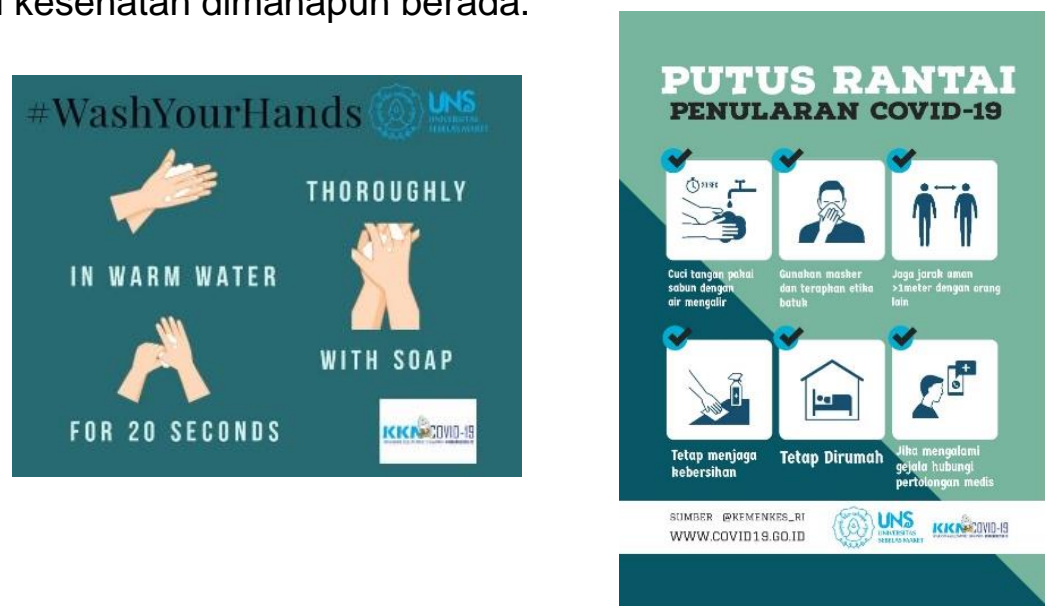

Gambar 2. Poster Ajakan Cuci Tangan Gambar 3. Poster Protokol Kesehatan

\section{\#StayAtHome.}

Pembatasan aktivitas diluar rumah selama pandemi Covid-19 sedang banyak digencarkan baik dari pemerintah pusat maupun pemerintah daerah demi menekan peningkatan kasus terdampak virus Covid-19. Semakin sedikit terjadinya kerumunan aktivitas manusia diharapkan dapat menekan kasus Covid-19. Pemerintah menghimbau agar bekerja, bermain dan beribadah dari rumah atau lebih dikenal \#StayAtHome. Gambar 4 dibawah merupakan ajakan kepada masyarakat khususnya yaitu masyarakat Kabupaten Kudus untuk tetap beraktivitas dirumah saja jika tidak ada kepentingan untuk keluar rumah. Dalam Gambar 5 dijelaskan berbagai kegiatan yang bisa dilakukan selama masa karantina (quarantine), sehingga tidak stress karena hanya beraktivitas dirumah saja
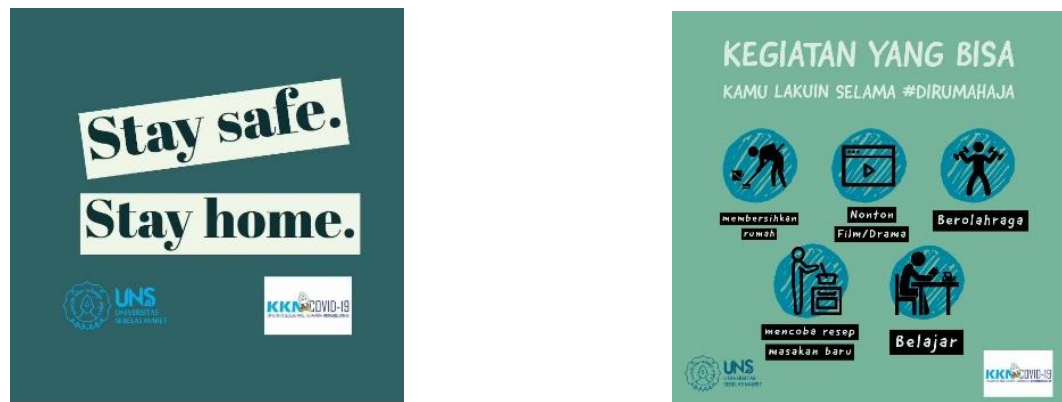

Gambar 4. Poster Ajakan \#StayAtHome Gambar 5. Poster Kegiatan \#StayAtHome 


\section{Physical Distancing.}

Himbuan yang dicanangkan oleh pemerintah untuk tetap melakukan aktivitas sehari - hari di rumah atau yang lebih dikenal stay at home masih belum berlaku secara efektif. Masih banyak ditemukan aktivitas - aktivitas masyarakat diluar rumah seperti yang ditemukan di Kabupaten Kudus. Pemberlakuan kebijakan stay at home menuai banyak sekali pro dan kontra. Salah satu protokol kesehatan yang diciptakan oleh pemerintah Indonesia dalam menangani kasus pelanggaran aktivitas diluar rumah adalah physical distancing. Dalam Gambar 6 ini dijelaskan mengenai pentingnya physical distancing apabila keluar rumah.

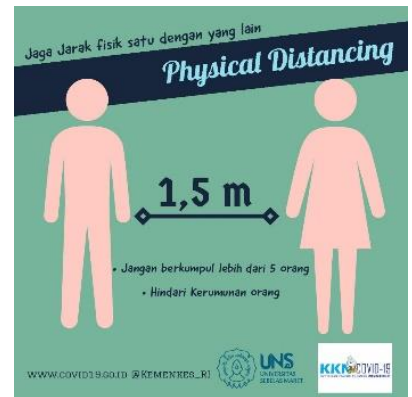

\section{Rapid Test.}

Gambar 6. Poster Physical Distancing

Dalam Gambar 7 ini dijelaskan tentang pengertian, serta penanganan yang harus dilakukan apabila negatif maupun positif.
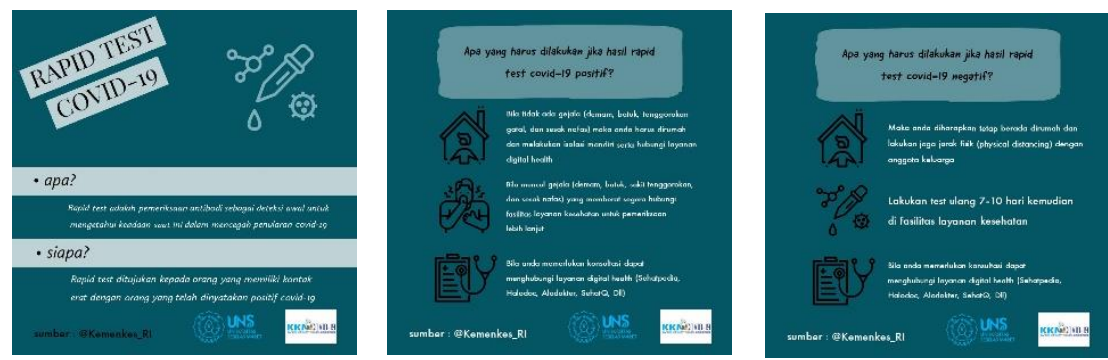

Gambar 7. Poster Penjelasan Rapid Test

\section{Langkah Giatkan Gotong Royong Hadapi Covid-19.}

Gambar dibawah ini dijelaskan berbagai cara agar dapat meningkatkan gotong royong antar masyarakat dalam menghadapi pandemi Covid-19.

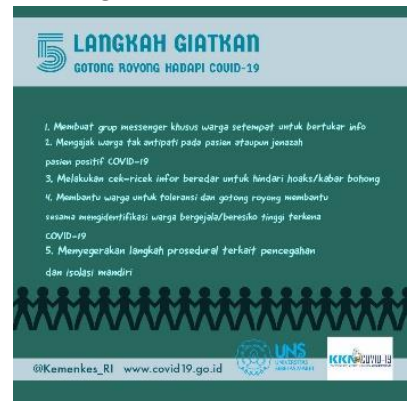

Gambar 8. Poster 5 Langkah Giatkan Gotong Royong Hadapi Covid-19

\section{Video Tutorial Cuci Tangan, Cara Pencegahan Penyebaran Covid-19 dan Pembuatan Masker Kain}

Video pertama yaitu video yang memiliki konsep seseorang yang sedang cuci tangan namun menggunakan cara yang salah, kemudian diberitahu mengenai cara cuci 
tangan yang baik dan benar. Diakhir video diberikan ajakan serta penjelasan pentingnya untuk cuci tangan secara rutin. Video kedua yaitu video berisi animasi yang menjelaskan mengenai bagaimana cara pencegahan penyebaran virus Covid-19. Video ketiga merupakan video yang menjelaskan secara bertahap mengenai cara pembuatan masker dari kain katun.

Ketiga video di atas kemudian di unggah ke Youtube dan Instagram TV (IGTV). Bersama setelah pengunggahan video, disertai dengan pembagian Kit Pembuatan Masker untuk anak muda. Berikut adalah alamat surel untuk mengakses ketiga video tersebut 1) Video Tutotrial Cuci Tangan : https://youtube.com/watch?v=bHnuKVFTg-I,
2) Video
Animasi
Pencegahan
Penyebaran
Virus
Covid-19

https://www.youtube.com/watch?v=Wzo0DNljJBY\&t=30s dan 3) Video Pembuatan Masker Kain ; https://www.youtube.com/watch?v=iTtZCI0UHJ4\&t=14s.
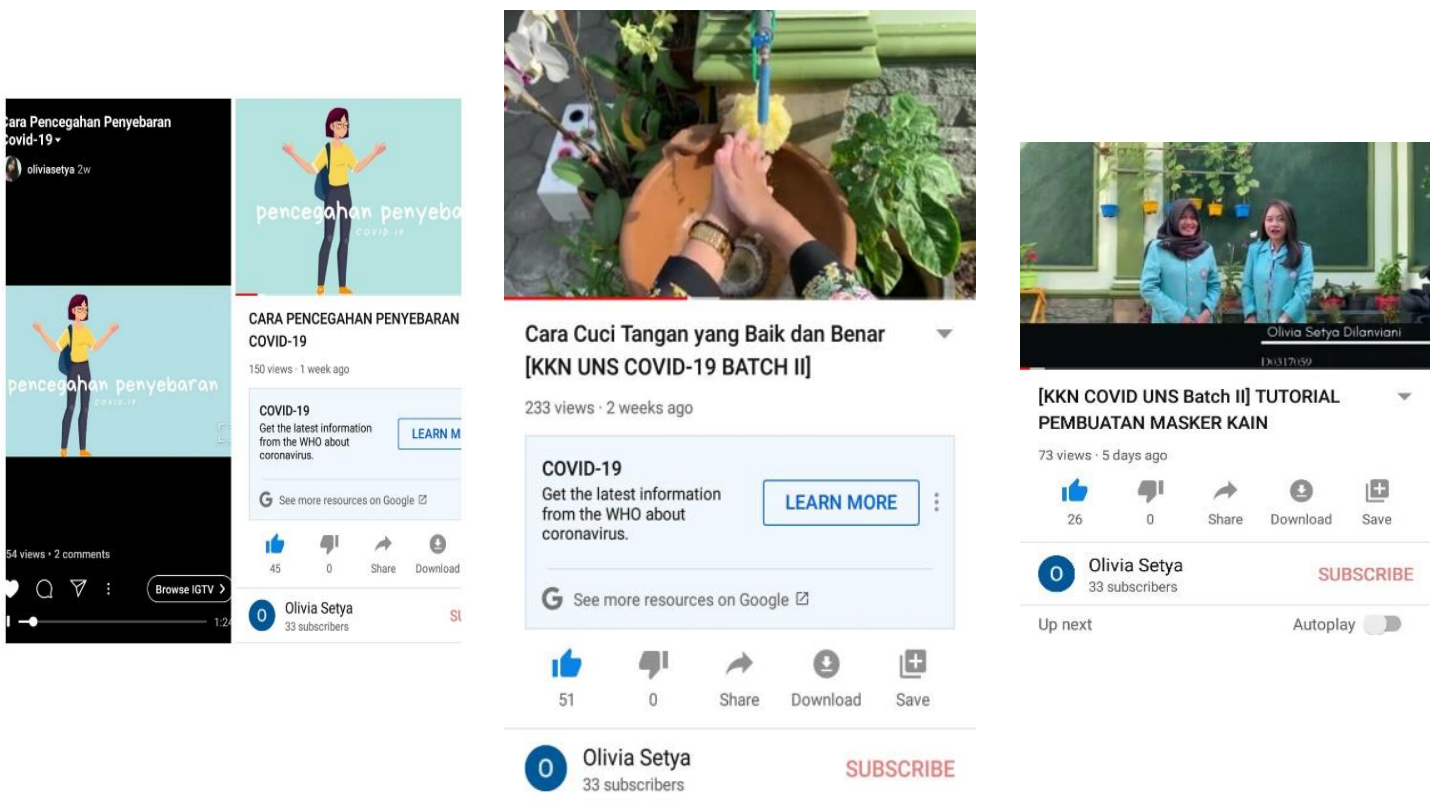

Gambar 9. Video Tutorial Cuci Tangan, Cara Pencegahan Penyebaran Covid-19 dan Pembuatan Masker Kain
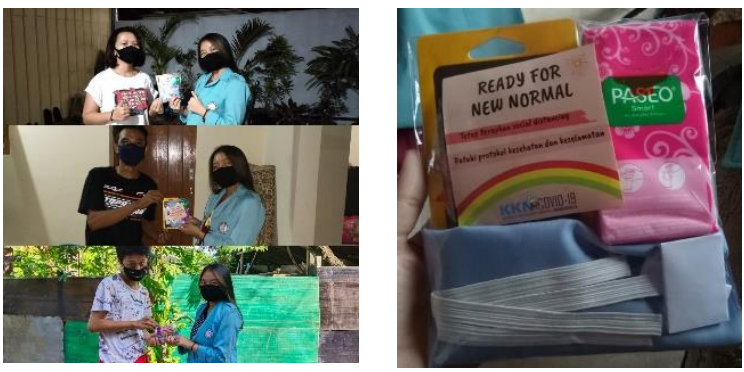

Gambar 10. Penyerahan Masker Kain

Berdasarkan poster dan video yang sudah diunggah di berbagai media sosial meliputi Instagram, Twitter dan Youtube, terdapat respon yang positif dari masyarakat Kabupaten Kudus, khususnya para pemuda atau anak-anak muda. Terdapat banyak sekali like, komentar dan views yang diberikan. Komentar yang sering diucapkan adalah mereka menjadi lebih paham dengan cara pencegahan penyebaran virus Covid-19 serta lebih mengerti dengan proses penyampaian yang lebih ringkas namun jelas. 


\section{SIMPULAN}

Pemanfaatan media sosial sebagai alat penyampaian informasi mengenai pencegahan penyebaran Covid-19 dirasa lebih mudah dan lebih menjangkau masyarakat, terutama pada para pemuda atau anak-anak muda. Selain itu juga dengan adanya kegiatan KKN UNS ini dapat meningkatkan pemahaman masyarakat akan pencegahan penyebaran Covid-19 sehingga dapat meminimalisir penyebaran Covid-19 di Kabupaten Kudus.

\section{DAFTAR PUSTAKA}

BPBD Kudus. 2020. "Infografis Kasus Covid-19 di Kabupaten Kudus hari Jumat, tanggal 15 Mei 2020 pukul 21.00 WIB". Instagram BPBD Kudus Kab. Tersedia di : https://www.instagram.com/p/CANt7YAjAJP/?igshid=r5ljaltvbgcu . Diakses pada tanggal 30 Juni 2020.

Pemerintah Kabupaten Kudus. 2020. "Surat edaran dari PIt. Bupati Kudus HM. Hartopo untuk diteruskan ke masyarakat". Instagram @Pemkabkudus. Tersedia di : https://www.instagram.com/p/B90Oip4hX3c/?igshid=12vkurybcdka0

Pranita, Ellyvon. 2020. "Pentingnya Peran Kaum Muda Lawan Virus Corona Pandemi Covid-19". Kompas.com. Tersedia di: https://www.kompas.com/sains/read/2020/04/ 08/090200623/pentingnya-perankaum-muda-lawan-virus-corona-pandemi-covid-19 Diakses pada tanggal 30 Juni 2020.

Mohammad, Yuliadi. 2020. "Pemkab Kudus Terus Gencarkan Sosialisasi Social Distancing dan Pemakaian Masker". Isknews.com. Tersedia di: https://isknews.com/pemkab-kudus-terus-gencarkan-sosialisasi-social-distancingdan-pemakaian-masker/ Diakses pada tanggal 30 Juni 2020 